\title{
PENGUKURAN KINERJA BANK UMUM SYARIAH DI INDONESIA BERDASARKAN SHARIA MAQASHID INDEX (SMI)
}

\author{
${ }^{1}$ Aneu Cakhyaneu \\ ${ }^{1}$ Program Studi Ekonomi dan Keuangan Islam, Universitas Pendidikan Indonesia \\ Jl. Dr. Setiabudhi No. 229 Bandung 40154 \\ 1aneufpeb@upi.edu
}

\begin{abstract}
Abstrak
Perbankan syariah di Indonesia berkembang sangat begitu pesat. Namun perkembangan tersebut nampaknya belum diimbangi dengan adanya pengukuran kinerja keuangan yang sesuai dengan tujuan syariah. Pengukuran kinerja bank syariah yang masih banyak digunakan saat ini masih terbatas pada pengukuran kinerja konvensional yang hanya menilai performance dari segi keuangan semata. Dengan demikian perlu adanya upaya pengukuran kinerja perbankan yang tidak hanya mengukur penilaian dari segi keuangan saja tetapi dinilai juga dari pencapaian tujuan syariah atau maqashid syariah untuk menciptakan kemaslahatan umat. Penelitian ini bertujuan untuk menganalisis kinerja bank umum syariah berdasarkan Sharia Maqashid Index (SMI) dengan menggunakan Simple Additive Weighthing Method $(S A W)$ yang dilakukan terhadap dua belas bank umum syariah di Indonesia. Hasil penelitian menunjukkan bahwa lima bank yang memiliki Sharia Maqashid Index tertinggi berturut turut adalah Bank Syariah Mandiri, Panin Bank Syariah, Bank Mega Syariah, BNI Syariah dan Bank Muamalat Indonesia.
\end{abstract}

Kata Kunci: Kinerja Bank Syariah, Sharia Maqashid Index (SMI)

\begin{abstract}
Syariah banking in Indonesia is growing very fast. These developments seem to have not been matched by the measurement of financial performance in accordance with the objectives of sharia. The measurement of the sharia banks performance that are still widely used today is still limited to convetional performance measurment that only assesses the performance of financial terms alone. Thus it is necessary to measure the performance of the banking system that not only measure the financial judgment but also judged from the achievement of the goal of shariah or maqashid shariah to create the benefit of the ummah. This study aims to analyze the performance of sharia banks based on Sharia Maqashid Index (SMI) with Simple Additive Weighting Method (SAW) conducted on twelve sharia banks in Indonesia. The results showed that the five banks that had the highest Sharia Maqashid Index respectively were Bank Syariah Mandiri, Panin Bank Syariah, Bank Mega Syariah, BNI Syariah and Bank Muamalat Indonesia.
\end{abstract}

Keywords: Sharia Banks Performance, Sharia Maqashid Index (SMI)

\section{PENDAHULUAN}

Perkembangan industri jasa keuangan di Indonesia saat ini tumbuh begitu pesat. Aset perbankan syariah mencatatkan pertumbuhan sebesar 24,2\% sampai Agustus 2017 (Bisnis.com, 2017) serta setiap tahunnya total aset perbankan syariah di Indonesia mengalami kenaikan. Adanya pertumbuhan tersebut mendorong daya saing yang tinggi diantara industri jasa keuangan terutama perbankan syariah yang harus dapat mempertahankan kinerjanya dengan baik

Received: 2018- 05-10| Reviced: 2018-07-31| Accepted: 2018-07-31

Indexed : DOAJ, Garuda, Crossref, Google Scholar | DOI: : https://doi.org/10.29313/amwaluna.v2i2.3753 
untuk tetap dapat bersaing secara sehat dengan

industri perbankan lainnya.

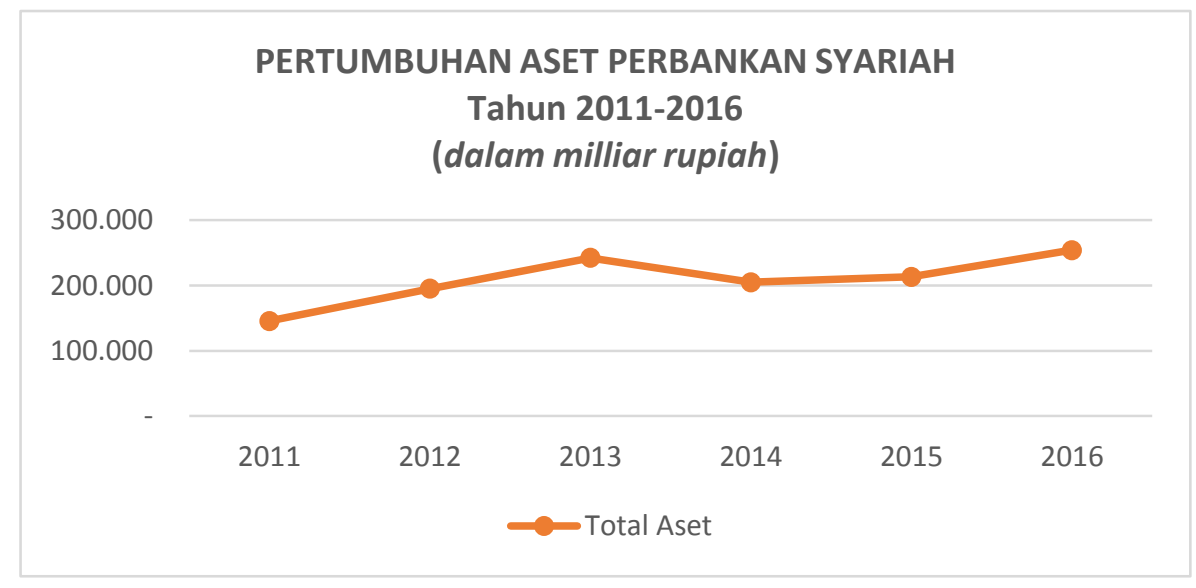

Gambar 1. Perkembangan Aset Perbankan Syariah di Indonesia

Pengukuran kinerja keuangan perbankan sangat penting dilakukan karena pengukuran kinerja merupakan gambaran pencapaian prestasi yang telah dilakukan dalam kegiatan operasionalnya sehingga dengan adanya pengukuran tersebut dapat diketahui kondisi kesehatan suatu bank. Untuk mengukur kinerja suatu bank digunakan metode penilaian yang telah umum digunakan yaitu dengan menggunakan analisis rasio keuangan yang kemudian hasilnya diinterprestasikan untuk membuat keputusan di periode yang akan datang (Veithzal Rivai, 2007).

Bank syariah maupun bank konvensional saat ini selalu melakukan

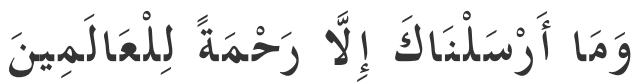

" Dan tidaklah kami mengutus kamu, melainkan untuk (menjadi) rahmatbi bagi semesta alam”(Q.S Al Anbiyaa: 107).

Pengukuran kinerja perbankan syariah di Indonesia masih banyak yang menggunakan pengukuran kinerja masing-masing bank salah satunya adalah dengan pengukuran rasio keuangan. Bank syariah adalah sebuah entitas bisnis syariah sehingga tidak hanya dituntut untuk mencari keuntungan semata (high profitability) tetapi juga harus dapat menjalankan fungsi dan tujuannya sebagai sebuah entitas syariah (good shariah objectives). Tujuan syariah yang harus dijalankan oleh perbankan syariah berkaitan dengan tujuan utama penciptaan manusia yaitu sebagai rahmat bagi seluruh alam. Hal ini merupakan tujuan pokok di mana Rasulullah SAW diutus ke dunia (Chapra, 2000).

pengukuran rasio keuangan yang digunakan di bank konvensional seperti CAMELS, Return on Asset (ROA), Return on Equity (ROE), Data Envelopment Analysis (DEA) (Al Ghifari, 2015). Penggunaan alat analisis rasio keuangan tersebut jika diterapkan pada pengukuran kinerja bank syariah memiliki 
banyak kelemahan serta tidak dapat sepenuhnya diterapkan karena bank syariah sebagai entitas bisnis syariah berbeda dengan bank konvensional sehingga tidak hanya dituntut untuk mengukur kinerja secara finansial saja tetapi harus juga diukur dari segi ketercapaian tujuan syariah yaitu maqashid syariah sehingga dapat diketahui apakah kinerja perbankan tersebut telah sesuai dengan nilai dan prinsip syariah atau belum (Afrinaldi, 2013). Maqashid syariah merupakan tujuantujuan umum yang ingin diraih oleh syariah yang diwujudkan dalam kehidupan sehingga menjadi salah satu konsep penting dalam kajian hukum islam (Febriadi, 2017). Pengukuran ketercapaian tujuan syariah pada perbankan tersebut dikenal dengan Sharia Maqashid Index (SMI) yang dikembangkan dari teori maqashid syariah oleh Abu Zahrah.

Pengukuran Sharia Maqashid Index (SMI) mengacu kepada teori maqashid syariah oleh Abu Zahrah yang mencakup tiga tujuan syariah yaitu Tahdzib al Fard (mendidik individu), Iqamah al-adl (menegakan keadilan) dan Jabl al-Maslahah (mencapai kesejahteraan). Ketiga tujuan tersebut

\section{KAJIAN PUSTAKA}

\section{Maqashid Syariah}

Maqashid syariah menurut Al Syatibi dalam (Ghifari, 2015) secara bahasa terdiri dari dua kata yaitu maqashid dan al-syariah. Maqashid berarti kesengajaan atau tujuan sedangkan al-syariah berarti jalan menuju sumber air, dapat pula dikatakan sebagai jalan ke arah sumber pokok kehidupan. Adapun ditransformasikan kedalam rasio kinerja untuk kemudian diinterprestasikan dalam menilai kinerja perbankan syariah. Meskipun pengukuran kinerja yang baru dikembangkan, namun penelitian-penelitian terkait Sharia Maqashid Index sudah mulai dilakukan. Penelitian yang dilakukan (Mohammed M. d., 2009), (Shaukat, 2008) dan (Hameed, 2004) menunjukkan bahwa praktek pengukuran kinerja dengan pendekatan Sharia Maqashid Index (SMI) merupakan solusi atas permasalahan yang ada mengenai pengukuran kinerja bank syariah. Pengukuran ini menggunakan indikator-indikator syariah sebagai alat ukurnya yang berbeda dengan alat ukur kinerja pada bank konvensional (Bedoui, 2012).

Berdasarkan pemaparan latar belakang di atas terkait pentingnya pengukuran Sharia Maqashid Index (SMI) pada perbankan syariah di Indonesia serta masih terbatasnya penelitian serupa yang dilakukan maka penulis mencoba melakukan penelitian untuk mengukur kinerja bank umum syariah di Indonesia dengan pendekatan Sharia Maqashid Index (SMI).

secara terminologi maqashid syariah menurut Abdul Wahab Khallaf "maqashid syariah adalah tujuan umum ketika Allah menetapkan hukum-hukum-Nya adalah untuk mewujudkan kemaslahatan manusia dengan terpenuhinya kebutuhan dharuriyah, hajiyah dan tahsiniyah" (Riyadi, 2014). Dengan demikian dapat dipahami bahwa tujuan maqashid syariah adalah untuk menciptakan kesejahteraan dan 
Aneu Cakhyaneu : Pengukuran Kinerja Bank Umum Syari'ah Di Indonesia....

kemaslahatan bagi seluruh umat baik di dunia maupun di akhirat.

Agar tujuan syariah (maqashidus syariah) dapat tercapai maka manusia harus mentaati dan melaksanakannya dalam kehidupan sehari-hari. Pencapaian tujuan syariah tersebut diantaranya adalah memelihara agama (Hifdz Ad-Din), memelihara jiwa (Hifdz An-Nafs), memelihara akal (Hifdz Al'Aql), memelihara keturunan (Hifdz An-Nasb) dan memelihara harta (Hifdz Al-Maal).

\section{Sharia Maqashid Index (SMI)}

Sharia Maqashid Index (SMI) merupakan metode yang dikembangkan oleh Mustafa Omar Mohammed, Dzuljastri Abdul Razak dan Fauziyah Md Taib dalam penelitiannya yang berjudul: The Performance Measures of Islamic Banking Based on the Maqashid Framework telah dirumuskan evaluasi kinerja perbankan syariah yang mengacu pada konsep maqashid syariah. Pengembangan Sharia Maqashid Index (SMI) didasari adanya ketidaksesuaian penggunaan indikator kinerja konvensional di perbankan syariah yang disebabkan oleh perbedaan tujuan antara indikator konvensional yang menitikberatkan hanya pada pengukuran keuangan sedangkan tujuan perbankan syariah bersifat multidimensional (Mohammed M. O., 2008).

Sharia Maqashid Index (SMI) dikembangkan dari teori maqashid syariah oleh Abu Zahrah yaitu mendidik individu (Tahfidz al Fard), menciptakan keadilan (Iqamah al adl) dan menciptakan kemaslahatan (Jabl al Maslahah). Masingmasing dimensi maqashid syariah tersebut memiliki elemen atau indikator yang dapat dijadikan ukuran untuk penilaian kinerja perbankan syariah sesuai dengan tujuannya yaitu menciptakan kesejateraan bagi umat.

\begin{tabular}{|l|l|l|}
\hline \multicolumn{1}{|c|}{ Tujuan Syariah } & \multicolumn{1}{|c|}{ Dimensi } & \multicolumn{1}{c|}{ Elemen } \\
\hline $\begin{array}{l}\text { Tahfidzal Fard (Mendidik } \\
\text { Individu) }\end{array}$ & $\begin{array}{l}\text { D1. Advancement } \\
\text { Knowledge }\end{array}$ & $\begin{array}{l}\text { E1. Education Grand } \\
\text { E2. Research }\end{array}$ \\
\cline { 2 - 3 } & $\begin{array}{l}\text { D2. Instilling new skill and } \\
\text { improvement }\end{array}$ & E3. Trainning \\
\cline { 2 - 3 } & $\begin{array}{l}\text { D3. Creating awareness of } \\
\text { islamic banking }\end{array}$ & E4. Publicity \\
\hline \multirow{5}{*}{$\begin{array}{l}\text { Iqamah al adl } \\
\text { (Menegakan Keadilan) }\end{array}$} & $\begin{array}{l}\text { D4. Fair Returns } \\
\text { D5. Cheap Products and } \\
\text { service }\end{array}$ & $\begin{array}{l}\text { E6. Fair Returns } \\
\text { Distribution }\end{array}$ \\
\cline { 2 - 3 } $\begin{array}{l}\text { D6. Elimination of } \\
\text { injustices }\end{array}$ & E7. Interest Free Product \\
(Mabl al Maslahah & D7. Profitability of bank & E8. Profit Rations \\
\cline { 2 - 3 } Kemaslahatan) & $\begin{array}{l}\text { D8. Redistribution of } \\
\text { income \& wealth }\end{array}$ & E9. Personal Income \\
\cline { 2 - 3 } & $\begin{array}{l}\text { D9. Invesment in real } \\
\text { sector }\end{array}$ & $\begin{array}{l}\text { E10. Invesment in real } \\
\text { sector }\end{array}$ \\
\hline
\end{tabular}

Sumber: (Mohammed M. O., 2008)

Tabel 1. Model Pengukuran Sharia Maqashid Index (SMI)

EISSN : 2540-8402 | ISSN : 2540-8399 
Terdapat tiga tahapan yang dilakukan untuk mengukur kinerja maqashid syariah bank (Afrinaldi, 2013) yaitu:

1. Menilai setiap rasio kinerja maqashid syariah yang terdiri dari sepuluh elemen rasio dengan indikator kinerja:
a. Education grand/Total expense (E1)
b. Research expense/Total expense (E2)
c. Trainning expense/Total expense (E3)
d. Publicity expense/Total expense (E4)
e. Profit equalization reserves $(P E R) /$ Net or invesment income (E5)

f. Mudharabah and musyarakah modes/Total invesment mode (E6)

g. Interest free income/Total income (E7)

h. Net income/Total asset (E8) i. Zakah paid/Net asset (E9)

$\mathrm{j}$. Invesment in real economic sectors/Total Invesment (E10)

2. Menetukan peringkat dari bank syariah berdasarkan Indikator Kinerja (IK)

Penentuan peringkat ini dilakukan dengan menggunakan Simple Additive Weighting Method (SAW) dengan cara pembobotan, agregat dan proses menentukan peringkat (weighting, aggregating and ranking processes) (Mohammed M. O., 2008).

3. Menetukan indeks maqashid syariah setiap bank

Sharia Maqashid Indeks

$(S M I)$ merupakan total semua kinerja indikator dari tiga tujuan maqashid syariah yang dirumuskan sebagai berikut:

\section{$\mathrm{SMI}=\mathrm{IK}(\mathrm{T} 1)+\mathrm{IK}(\mathrm{T} 2)+\mathrm{IK}(\mathrm{T} 3)$}

(Mohammed M. O., 2008)

\section{METODE PENELITIAN}

Penelitian ini dilakukan untuk mengukur kinerja bank umum syariah di Indonesia dengan menggunakan Sharia Maqashid Index (SMI). Adapun metode penelitian yang digunakan adalah metode deskriptif dengan pendekatan kuantitatif. Penelitian deskriptif mempelajari masalahmasalah dalam masyarakat, serta tata cara yang berlaku dalam masyarakat serta situasisituasi tertentu termasuk tentang hubunganhubungan, kegiatan-kegiatan, sikap-sikap serta proses-proses yang sedang berlangsung dan pengaruh-pengaruh dari suatu fenomena (Nazir, 2003). Penelitian ini akan menggambarkan kinerja bank umum syariah berdasarkan pengukuran Sharia Maqashid Index (SMI) serta diinterprestasikan bank umum syariah mana yang memiliki index maqashid syariah yang paling tinggi.

Secara singkat adapun prosedur dalam penelitian ini dilakukan sebagai berikut:

1. Masing-masing tujuan syariah dalam Sharia Maqashid Index (SMI) yaitu mendidik individu, menegakan keadilan serta menciptakan kesejahteraan dijabarkan ke dalam beberapa dimensi dimana setiap dimensi tersebut merupakan rasio kinerja yang diperoleh 
Aneu Cakhyaneu : Pengukuran Kinerja Bank Umum Syari'ah Di Indonesia....

berdasarkan perhitungan rasio keuangan setiap bank;

2. Melakukan pembobotan, agregat untuk menentukan peringkat dari masingmasing indikator kinerja yang diperoleh berdasarkan perhitungan rasio keuangan setiap bank;

3. Menentukan indeks maqashid syariah setiap bank dengan menjumlahkan semua bobot kinerja untuk menentukan bank syariah mana yang memiliki nilai indeks tertinggi.

Adapun populasi dalam penelitian ini adalah Bank Umum Syariah (BUS) yang beroperasi di Indonesia sampai tahun 2016 yaitu sebanyak 12 BUS. Semua pupulasi dalam penelitian dijadikan sampel. Oleh karena itu tekhnik sampling yang digunakan adalah sampling jenuh, dengan 12 sampel Bank Umum Syariah (BUS) diantaranya adalah Bank Syariah Mandiri (BSM), Bank
Muamalat Indonesia, BNI Syariah, BRI Syariah, Bank Mega Syariah, BCA Syariah, BJB Syariah, Bank Syariah Bukopin, Maybank Syariah Indonesia, Panin Bank Syariah, Bank Viktoria Syariah dan BTPN Syariah.

Teknik pengumpulan data yang dilakukan dalam penelitian ini adalah dengan teknik dokumentasi melalui data sekunder berupa laporan keuangan (Annual Report) Bank Umum Syariah dari tahun 2011-2016 yang dipublikasi di www.ojk.go.id serta studi kepustakaan yang bertujuan untuk memperoleh konsep dan landasan teori dengan mengkaji berbagai literatur, jurnal dan dokumen-dokumen yang berkaitan dengan objek penelitian. Adapun operasionalisasi variabel dalam penelitian ini adalah sebagai berikut:

\begin{tabular}{|c|c|c|c|c|c|}
\hline Variabel & $\begin{array}{l}\text { Konsep } \\
\text { Teoritis }\end{array}$ & Dimensi & Elemen & Indikator & $\begin{array}{l}\text { Jenis } \\
\text { Data }\end{array}$ \\
\hline \multirow{4}{*}{$\begin{array}{ll}\text { Tahfidz al } \\
\text { Fard } \\
\text { (Mendidik } \\
\text { individu) }\end{array}$} & & $\begin{array}{l}\text { Meningkatkan } \\
\text { pengetahuan }\end{array}$ & Pendidikan & $\begin{array}{l}\text { Hibah } \\
\text { pendidikan/Total } \\
\text { Beban }\end{array}$ & Rasio \\
\hline & & & Penelitian & $\begin{array}{l}\text { Hibah } \\
\text { penelitian/Total } \\
\text { Beban }\end{array}$ & Rasio \\
\hline & & $\begin{array}{l}\text { Menambah } \\
\text { dan } \\
\text { meningkatkan } \\
\text { kemampuan } \\
\text { baru }\end{array}$ & Pelatihan & $\begin{array}{l}\text { Biaya } \\
\text { pelatihan/Total } \\
\text { beban }\end{array}$ & Rasio \\
\hline & & $\begin{array}{l}\text { Menciptakan } \\
\text { kesadaran } \\
\text { masyarakat } \\
\text { akan } \\
\text { keberadaan } \\
\text { bank syariah }\end{array}$ & Publikasi & $\begin{array}{l}\text { Biaya } \\
\text { publikasi/Total } \\
\text { beban }\end{array}$ & Rasio \\
\hline $\begin{array}{l}\text { Iqamah al adl } \\
\text { (Menegakan } \\
\text { keadilan) }\end{array}$ & & $\begin{array}{l}\text { Kontrak yang } \\
\text { adil }\end{array}$ & $\begin{array}{l}\text { Pengembalian } \\
\text { yang adil }\end{array}$ & $\begin{array}{l}\text { Profit } \\
\text { equalization } \\
\text { reserves } \\
(\text { PER } / \mathrm{Net}\end{array}$ & Rasio \\
\hline
\end{tabular}




\begin{tabular}{|c|c|c|c|c|}
\hline & & & invesment income & \\
\hline & $\begin{array}{l}\text { Produk dan } \\
\text { layanan } \\
\text { terjangkau }\end{array}$ & $\begin{array}{l}\text { Fungsi } \\
\text { distribusi }\end{array}$ & $\begin{array}{l}\text { Mudharabah dan } \\
\text { musyarakah/Total } \\
\text { investasi }\end{array}$ & Rasio \\
\hline & $\begin{array}{l}\text { Penghapusan } \\
\text { ketidakadilan }\end{array}$ & $\begin{array}{l}\text { Produk non } \\
\text { bunga }\end{array}$ & $\begin{array}{ll}\text { Pendpatan } & \text { non } \\
\text { bunga/total } & \\
\text { pendapatan } & \\
\end{array}$ & Rasio \\
\hline \multirow{3}{*}{$\begin{array}{l}\text { Jabl al } \\
\text { Maslahah } \\
\text { (Menciptakan } \\
\text { Kemaslahatan) }\end{array}$} & Profitabilitas & Rasio Laba & $\begin{array}{l}\text { Laba bersih/total } \\
\text { aset }\end{array}$ & Rasio \\
\hline & $\begin{array}{l}\text { Pendistribusian } \\
\text { kekayaan dan } \\
\text { laba }\end{array}$ & $\begin{array}{l}\text { Pendapatan } \\
\text { personal }\end{array}$ & Zakat/net aset & Rasio \\
\hline & $\begin{array}{l}\text { Investasi pada } \\
\text { sektor rill yang } \\
\text { vital }\end{array}$ & $\begin{array}{l}\text { Rasio } \\
\text { investasi pada } \\
\text { sektor rill }\end{array}$ & $\begin{array}{lr}\text { Investasi } & \text { pada } \\
\text { sektor rill/total } \\
\text { penyaluran } \\
\text { investasi }\end{array}$ & Rasio \\
\hline
\end{tabular}

Tabel 2. Operasionalisasi variabel

\section{PEMBAHASAN}

\section{Sharia Maqashid Indeks (SMI)} merupakan total semua indikator kinerja dari tiga tujuan maqashid syariah yaitu Tahfidz al Fard (mendidik individu), Iqamah al adl (Menegakan keadilan) dan Jabl al Maslahah (Menciptakan Kemaslahatan). Adapun hasil perhitungan kinerja Bank Umum Syariah untuk tujuan pertama (Tahfidz al Fard) adalah sebagai berikut:

\begin{tabular}{|c|c|c|c|c|}
\hline \multirow{2}{*}{ Bank } & \multicolumn{4}{|c|}{ Rasio Kinerja Tujuan 1 } \\
\cline { 2 - 5 } & R $\mathbf{1 . 1}$ & $\mathbf{R} \mathbf{. 1}$ & R3.1 & R4.1 \\
\hline BCAS & 0,02 & 0,00 & 1,41 & 1,05 \\
\hline BJBS & 0,01 & 0,00 & 0,00 & 2,06 \\
\hline BMS & 0,05 & 0,00 & 0,26 & 0,46 \\
\hline BMI & $\mathbf{0 , 6 1}$ & $\mathbf{0 , 2 2}$ & 1,09 & 3,75 \\
\hline BNIS & 0,32 & 0,00 & $\mathbf{3 , 4 7}$ & $\mathbf{1 4 , 8 2}$ \\
\hline BRIS & 0,02 & 0,00 & 2,51 & 2,87 \\
\hline BSB & 0,00 & 0,00 & 1,68 & 2,41 \\
\hline BSM & 0,37 & 0,08 & 1,12 & 2,45 \\
\hline BVS & 0,00 & 0,00 & 0,30 & 0,63 \\
\hline MSI & 0,18 & 0,00 & 0,34 & 0,61 \\
\hline PBS & 0,01 & 0,00 & 0,76 & 0,57 \\
\hline BTPNS & 0,00 & 0,00 & 0,07 & 0,04 \\
\hline
\end{tabular}

Tabel 3. Nilai Rata-rata Rasio Kinerja Maqashid Syariah Tujuan Pertama (Tahdzib al Fard) BUS Tahun 2011-2016
Bank syariah yang memperoleh rasio Education Grand (pendidikan) yang paling tinggi adalah BMI dengan nilai rasio sebesar $0,61 \%$ hal ini menunjukkan bahwa dari total pengeluaran/biaya sebesar $0,61 \%$ ditujukan untuk donasi pendidikan. Rasio kedua dari tujuan pertama adalah research dengan perolehan rasio tertinggi pada BMI. Rasio yang ketiga yaitu trainning dengan rasio tertinggi diperoleh BNIS sedangkan rasio keempat terakhir dari tujuan maqashid syariah yang pertama adalah publicity dengan rasio tertinggi $14,82 \%$ pada BNIS. Dengan demikian dapat disimpulkan bahwa pada tujuan pertama ini Tahfidz al Fard (mendidik individu) BMI dan BNI Syariah yang memiliki rasio kinerja yang paling tinggi dibanding BUS lainnya pada tahun 2011-2016.

Hasil selanjutnya dari penelitian ini adalah nilai kinerja BUS untuk tujuan kedua yaitu Iqamah al-Adl (menegakan keadilan) sebagaimana terlihat dalam tabel berikut.

\section{Bank $\quad$ Rasio Kinerja Tujuan 2}




\begin{tabular}{|c|c|c|c|}
\hline & $\mathbf{R}_{\mathbf{1 . 2}}$ & $\mathbf{R} \mathbf{2 .}$ & $\mathbf{R 3 . 2}$ \\
\hline BCAS & 0,00 & 46,03 & 99,95 \\
\hline BJBS & 0,00 & 28,25 & 99,80 \\
\hline BMS & 0,00 & 0,73 & 98,61 \\
\hline BMI & 0,00 & 57,66 & 99,95 \\
\hline BNIS & 0,00 & 17,79 & 98,05 \\
\hline BRIS & 0,00 & 29,38 & 97,46 \\
\hline BSB & 0,00 & 37,74 & 99,92 \\
\hline BSM & 0,00 & 27,11 & 99,97 \\
\hline BVS & 0,00 & 34,82 & 99,73 \\
\hline MSI & 0,00 & 23,27 & 9,98 \\
\hline PBS & 0,00 & $\mathbf{6 5 , 8 8}$ & $\mathbf{1 0 0 , 0 0}$ \\
\hline BTPNS & 0,00 & 0,00 & 99,99 \\
\hline
\end{tabular}

Tabel 4. Nilai Rata-rata Rasio Kinerja Maqashid Syariah Tujuan Kedua (Iqamah al-Adl) BUS Tahun 2011-2016

Rasio kinerja pertama dari tujuan maqashid syariah kedua Iqamah al-Adl (menegakan keadilan) yaitu Fair Return. Berdasarkan perhitungan, belum ada bank syariah yang melaporkan alokasi dana untuk rasio Profit Equalization Reserves (PER) pada laporan keuangannya. Rasio kedua dari tujuan syariah ini adalah fungtional disribution dimana nilai rasio tertinggi diperoleh Panin Bank Syariah (PBS) dengan nilai rasio $65,88 \%$. Hal ini menunjukkan bahwa pembiayaan yang diberikan oleh PBS sebagian besar banyak dilakukan dengan akad mudharabah dan musyarakah dibandingkan BUS lainnya. Demikian pula dengan rasio Interest Free Income, nilai rasio tertinggi diperoleh Panin Bank Syariah (PBS). Dari keseluruhan rasio Interest Free Income ini sebagian besar BUS menunjukkan bahwa pendapatannya bukan berasal dari riba/bunga melainkan dari bagi hasil dan margin.

Tujuan maqashid syariah yang ketiga adalah Jabl al Maslahah (Menciptakan
Kemaslahatan). Tujuan syariah ketiga ini diperoleh dengan tiga buah indikator kinerja yaitu profit ratios, personal income dan invesment in real sector. Adapun nilai dari ketiga rasio pada tujuan maqashid syariah tujuan ketiga Jabl al Maslahah ini adalah sebagai berikut:

\begin{tabular}{|c|c|c|c|}
\hline \multirow{2}{*}{ Bank } & \multicolumn{3}{|c|}{ Rasio Kinerja Tujuan 3 } \\
\cline { 2 - 4 } & $\mathbf{R}_{\mathbf{1 . 3}}$ & $\mathbf{R} \mathbf{2 . 3}$ & $\mathbf{R 3 . 3}$ \\
\hline BCAS & 0,57 & 0,00 & 67,26 \\
\hline BJBS & 0,38 & 0,00 & 72,46 \\
\hline BMS & 0,86 & $\mathbf{0 , 0 7}$ & 82,32 \\
\hline BMI & 0,34 & 0,02 & 69,25 \\
\hline BNIS & 0,38 & 0,04 & 77,77 \\
\hline BRIS & 0,28 & 0,03 & 77,30 \\
\hline BSB & 0,41 & 0,00 & 73,34 \\
\hline BSM & 0,76 & 0,04 & $\mathbf{8 3 , 0 3}$ \\
\hline BVS & 0,10 & 0,02 & 72,68 \\
\hline MSI & $\mathbf{1 , 3 6}$ & 0,00 & 65,02 \\
\hline PBS & 0,85 & 0,01 & 74,39 \\
\hline BTPNS & 0,04 & 0,00 & 78,99 \\
\hline
\end{tabular}

Tabel 5. Nilai Rata-rata Rasio Kinerja Maqashid Syariah Tujuan Ketiga (Jalb al-Maslahah) BUS Tahun 2011-2016

Rasio pertama profit ratios tertinggi diperoleh oleh Mybank Syariah Indonesia (MSI) dengan nilai rasio sebesar 1,36\%. Rasio kedua yaitu personal income nilai tertinggi diperoleh Bank Mega Syariah (BMS) dengan rasio sebesar $0,07 \%$ untuk pembayaran zakat dari total aset bersih sedangkan nilai rasio tertinggi ketiga yaitu invesment in real sector diperoleh BSM dengan rasio sebesar 83,03\% ini merupakan wujud bank berinvestasi dalam sektor riil. Berdasarkan hasil perhitungan masing-masing tujuan maqashid syariah tersebut selanjutnya dihitung nilai Sharia Maqashid Index (SMI) sebagai berikut: 


\begin{tabular}{|c|l|l|l|c|c|}
\hline \multirow{2}{*}{ Bank } & \multicolumn{5}{|c|}{ Sharia Maqashid Index (SMI) } \\
\cline { 2 - 6 } & IK-T1 & IK-T2 & IK-T3 & SMI & Rank \\
\hline BCAS & 0,000014 & 0,0859 & 0,10926 & 0,19517 & 9 \\
\hline BJBS & 0,000172 & 0,0688 & 0,13722 & 0,20619 & 8 \\
\hline BMS & 0,00361 & 0,0534 & 0,19769 & 0,25472 & 3 \\
\hline BMI & 0,00163 & 0,1015 & 0,12063 & 0,22376 & 5 \\
\hline BNIS & 0,00517 & 0,0742 & 0,16914 & 0,24852 & 4 \\
\hline BRIS & 0,00017 & 0,0254 & 0,14401 & 0,16958 & 10 \\
\hline BSB & 0,00043 & 0,0747 & 0,14454 & 0,21967 & 6 \\
\hline BSM & $\mathbf{0 , 0 0 6 1 1}$ & 0,0623 & $\mathbf{0 , 2 0 8 5 5}$ & $\mathbf{0 , 2 7 6 9 6}$ & $\mathbf{1}$ \\
\hline BVS & 0,00007 & 0,0733 & 0,13731 & 0,21068 & 7 \\
\hline MSI & 0,00009 & 0,0657 & 0,10018 & 0,16597 & 11 \\
\hline PBS & 0,00009 & $\mathbf{0 , 1 2 0 9}$ & 0,14477 & 0,26576 & 2 \\
\hline BTPNS & 0,00015 & 0,0517 & 0,17410 & 0,22595 & 12 \\
\hline
\end{tabular}

Tabel 6. Sharia Maqashid Index (SMI)

Bank Umum Syariah

Tahun 2011-2016

Berdasarkan hasil perhitungan Sharia Maqashid Index (SMI) di atas, bank yang memiliki nilai index tertinggi pertama adalah BSM, peringkat kedua tertinggi adalah Panin Bank Syariah (PBS) peringkat ketiga diraih oleh Bank Mega Syariah (BMS). Bank Umum Syariah selanjutnya yang memiliki peringkat Sharia Maqashid Index (SMI) tertinggi keempat dan kelima adalah BNI Syariah dan Bank Muamalat Indonesia (BMI). Adapun lima Bank Umum Syariah yang memperoleh Sharia Maqashid Index (SMI) terendah berturut turut adalah BJBS, BCA Syariah, BRI Syariah, Maybank Syariah Indonesia (MSI) dan BPTN Syariah dengan Sharia Maqashid Index (SMI) terendah diantara Bank Umum Syariah di Indonesia pada tahun 2011-2016.

\section{SIMPULAN}

Pengukuran kinerja berdasarkan maqashid syariah bagi Bank Umum Syariah (BUS) dapat diukur dengan menggunakan Sharia Maqashid Index (SMI). Nilai rata-rata
Sharia Maqashid Index (SMI) yang diperoleh BUS di Indonesia sebagian besar telah menjalankan kegiatan operasionalnya dan telah memenuhi standar pengukuran kinerja berdasarkan maqashid syariah.

Hasil pengukuran kinerja BUS pada tahun 2011-2016 berdasarkan Sharia Maqashid Index (SMI), diperoleh bank umum yang memiliki index maqashid syariah tertinggi adalah BSM. Hal ini dikarenakan BSM yang paling dominan dalam melaksanakan tujuan maqashid yang pertama Tahdzib al-Fard dan tujuan ketiga Jalb alMaslahah sehingga hal ini mampu menjadikan bank tersebut memperoleh nilai Sharia Maqashid Index (SMI) tertinggi dibandingkan bank umum syariah lainnya. Sebaliknya bank yang memperoleh Sharia Maqashid Index (SMI) terendah adalah BPTN Syariah, hal ini dikarenakan bank tersebut belum maksimal dalam melaksanakan tiga tujuan maqashid syariah terutama dalam pelaksanaan tujuan 
Aneu Cakhyaneu : Pengukuran Kinerja Bank Umum Syari'ah Di Indonesia....

pertama yaitu mendidik individu (Tahdzib al-

Fard).

\section{DAFTAR PUSTAKA}

Afrinaldi. (2013). Analisis Kinerja Perbankan Syariah indonesia ditinjau dari Maqashid Syariah: Pendekatan Sharia Maqashid Index (SMI) dan Profitabilitas Bank Syariah. Jakarta: Islamic Economic \&Finance (IEF) Universitas Trisakti.

Al Ghifari, L. H. (2015). Analisis KInerja Perbankan Syariah di Indonesia dan Malaysia dengan Pendekatan Maqashid Sharia Index. Jurnal Ekonomi dan Perbankan Syariah Vol 3 No 2, 4.

Bedoui, M. (2012). Sharia Based Ethical Performance Measurement Framework .

Bisnis.com. (2017, Oktober). Diambil kembali dari Finansial.bisnis.com: http://finansial.bisnis.com/read/20171 018/90/700518/aset-perbankansyariah-per-agustus-2017-tumbuh-242

Chapra, U. (2000). Sistem Moneter Islam. Jakarta: Gema Insani.

Febriadi, S. R. (2017). Aplikasi Maqashid Syariah dalam Bidang Perbankan Syariah. Amwaluna, 231.
Ghifari, M. (2015). Analisis Kinerja Perbankan Syariah di Indonesia dan Malaysia dengan Pendekatan Maqashid Syariah. Jurnal Ekonomi dan Perbankan Syariah Vol.3 No.2.

Hameed, S. P. (2004). Alternative Diclosure and Performance Measures for Islamic Bank. Working Paper IIUM .

Mohammed, M. d. (2009). Testing the Performance Measures Based on Maqashid al-Sharia (PMMS) 24 Model Selected Islamic and Conventional Bank.

Mohammed, M. O. (2008). The Performance Measures of Islamic Banking Based on the Maqashid Framework. Paper Presented at the IIUM International Accounting Conference (INTAC IV).

Nazir, M. (2003). Metode Penelitian. Jakarta: PT Ghalia Indonesia.

Riyadi, I. (2014). Prinsip Dasar Ekonomi Islam Perspektif Maqashid Al-Syariah. Jakarta: Kencana.

Shaukat, M. (2008). The Recent Financial Growth of Islamic Bank and Their Fulfilment of Maqashid al Sharia Gap Analysis. Working Journal INCEIF Malaysia.

Veithzal Rivai, d. (2007). Bank and Finance Institutions Management: Conventional and Sharia System. Jakarta: Raja Grafindo Persada. 